\title{
The Pure Church Movement
}

Peter Hoover

Rocky Cape Christian Community

Detention River

Tasmania, Australia

\begin{abstract}
The "Pure Church Movement" is introduced as a plain Anabaptist revival that unfolded in American, Canadian, and Latin American Swiss Mennonite, Russian Mennonite, and Amish churches over the course of the 20th century. It was an intentional return to the ideals they perceived "early Anabaptists" held. The pressures prompting this re-evaluation were both a protest against what members perceived as the bondage of spiritually-dead traditionalism and church slackness (Old Order) as well as a protest against the supposed reforms of late 19th century Protestant-influenced revivals, which led by-and-large to 20th century assimilation. Distinctive emphases of the Pure Church Movement include a strong practice of church discipline; a propensity to make frequent and drastic changes when such changes are felt to bring the church closer to early Anabaptism and Scripture teachings; agriculture and other within-community employment, especially that which employs the family; high mobility despite strong transportation restrictions; and a rejection of outside methods, especially those of evangelical Protestants, to achieve revival. The history of the Pure Church Movement is highly varied-geographically, chronologically, and ideologically. This article traces its origins and complex developments, beginning with groups such as the Reformed Amish Christian Church, the David Martin Mennonites, Reidenbach Mennonites, and Titus Hoover group. Today, the Pure Church Movement consists of two currents: (1) those basically Old Order but having adopted Pure Church Principles, e.g. David Martin and Reidenbach Mennonites, and (2) the radical stream, e.g. the Orthodox Mennonites, Hoover Mennonites, and Believers in Christ (Lobelville, TN) communities.
\end{abstract}

\section{Keywords}

Early Anabaptism; Hoover Mennonite; Orthodox Mennonite; Pilgrimage Valley, Belize; Barton Creek, Belize; Scottsville, KY; Stauffer Mennonite; Reidenbach Mennonite; Old Order; Reformed Amish Christian Church; St. Joe, Arkansas; Mammoth Springs, Arkansas; Hohenwald, Tennessee; Lobelville, Tennessee; Cookeville, Tennessee; Virginia Old Order Mennonite; Ontario Old Order Mennonite

\section{Acknowledgement}

The journal's editor assisted in fact-checking and in the completion of this article.

Address correspondence to: Peter Hoover, Rocky Cape Christian Community, 19509 Bass Highway, Detention River, Tasmania 7321, Australia; peterhoover.tas@gmail.com

Recommended citation: Hoover, Peter. 2018. “The Pure Church Movement.” Journal of Amish and Plain Anabaptist Studies 6(1):73-99. 


\section{Editor's Preface: Rethinking Our Anabaptist Movement Categories}

For scholars, Anabaptist movements presently number three: the Old Orders, the Conservatives, and the Mainstream. These three movements became identifiable through the 1800s in North America, as each of the religious traditions arriving in the 1700s and early 1800s - Swiss Mennonite, Amish, and Brethren — responded to their new host society. Some denominations embraced their new society, becoming mainstream. Some rejected it, retaining the Old Order. Some hybridized American evangelicalism with Anabaptist ideals, becoming Conservative. These have been useful distinctions. Indeed, in the first issue of JAPAS, I used it to define our material of interest, as of the Old Orders and Conservatives. But the three typologies have problems. They have become unresponsive and unchanging, despite well over a century since the movements were identified and characterized.

And changes have occurred. For one, a century's worth of American history has provided opportunity for additional movements. Then also, constant internal changes have turned, for example, some Old Orders into people quite responsive to the American mainstream. As an inverse example, generations of relative stasis has turned some Conservatives into, in essence, Old Order Conservatives. Sunday school and revival meetings in these churches are about as predictable and formulated as the Loblied. Furthermore, Old Order / Conservative / Mainstream maladroitly fit the Russian Mennonites, Apostolics, Hutterites, and Bruderhof. After all, their migrations to North America occurred during and after the Amish, Brethren, and Swiss Mennonite traditions were already splintering into these three movements. Even then, within the three early migrating traditions, the awkward fits to these three movements are many, including, the Holdeman Mennonites, Reformed Mennonites, Stauffer Mennonites, David Martin Mennonites, Remnant (i.e. "Charity”) churches, New New Order Amish, the Tampico and Midwest Beachy Amish-Mennonites (who have Old Order-style services with German), the New Old German Baptist Brethren, the "Reconciliation Amish,” and others.

Herein, Peter Hoover has thoroughly chronicled the "Pure Church Movement” (having been raised in a branch of it). In so doing, he makes a significant step toward advancing our understanding of movement typologies. No longer do the Old Order and Conservative movements solely represent plain Anabaptists. Hoover demonstrates that the Pure Church movement stands alone in its own right. The casual reader will benefit from the Introduction and Definitions, while the remaining descriptions of 35 groups are meticulous data for his argument.

With such a detailed account, we as both author and editor expect some discrepancies to arise. Reviewers familiar with portions of this history have already identified some. Yet, given the choice between postponing publication until all facts can be verified and releasing it for consideration without, we have chosen the latter. In so doing, we invite those who can speak to the material to send us suggested updates and corrections.

—Cory Anderson, JAPAS editor 


\section{Introduction}

Leaving European state churches they perceived as intrinsically corrupt, all early Anabaptists strove to present to Christ a "radiant church"-a holy bride-"without spot or wrinkle, blameless and pure" (Ephesians 5:25-27). This high standard of purity, they believed, can only be maintained in fellowships where all have abandoned themselves to Christ, inwardly and in their daily walk, where all submit one to another out of devotion to Christ, taking responsibility to admonish, correct and encourage as needed. The opposite of this purity-sin, stubbornness, and failure to live in godly harmony — could only be handled through the ban and social avoidance.

Already in the first Anabaptists' time, their pure church ideal led them into earnest yet totally irreconcilable disagreements with one another. The Frisian-Flemish division of 1565, like the Amish division of the 1690s, were only the beginning of many more to follow. To agree on an exact standard for church purity was not easily achieved. Every generation's struggle with personal sins and the infinite variety of new challenges to church order and discipline kept them occupied with the issue wherever they settled, in the Old World and the New.

Invariably, however, as Mennonite, Amish, and Hutterite settlements matured and stabilized, their original standards of purity sagged or —in the eyes of some- -broke down altogether. Larger settlements took on characteristics of the old European Volkskirchen (peoples' churches), where the zealous and the slack, the earnestly religious and the worldly-focused, coexisted in a society ample enough and stable enough to accommodate all.

In America, among the first to protest this loss of vision and to return with similarly concerned Anabaptists to the ideal of the pure church were John Herr, founder of the Reformed Mennonite Church in 1812; Jacob W. Stauffer, founder of the Stauffer Mennonite Church in 1845; and John Holdeman, founder of the Church of God in Christ, Mennonite ("Holdeman churches”) in 1859. In all three cases, leaders of the new fellowships turned to the writings of early Anabaptists, particularly to Menno Simons and Dirk Philips, for direction. In the three new movements, a return to a high level of commitment one to another within the brotherhood, coupled with rigid discipline - the ban and avoidance for those who broke fellowship-resulted in extraordinarily close-knit, homogenous fellowships, appealing to earnest seekers. Deep-going trauma and personal distress followed those who were separated from them.

The subject of this article, however, is a distinct movement, described here as the Pure Church Movement (for want of an official name) that arose among North American Mennonites in markedly different circumstances after the 1890s. The Pure Church Movement arose not only as a protest against church slackness but as a protest against another method of purifying the church-that of late $19^{\text {th }}$ century Protestant-influenced revivals. The Pure Church Movement was an intentional return to the ideals they perceived "early Anabaptists" held. The pressures 
prompting this re-evaluation were both $20^{\text {th }}$ century assimilation on the one hand and-what leaders perceived as - the bondage of spiritually-dead traditionalism on the other.

What makes the Pure Church Movement unique among conservative Anabaptists is its simultaneous origin among Amish, Swiss Mennonite, and Russian Mennonite religious traditions. Its propensity to merge small groups of like-minded believers, to mingle families of all Anabaptist backgrounds, and to attract seekers from contemporary lifestyles into a very conservative setting - while maintaining numerous internal divisions in varied degrees of fellowship-have given the Pure Church Movement a complex but vibrant character of its own.

\section{Defining the Pure Church Movement}

The Pure Church Movement was born in the conflict created by the impact of North American revivalism upon the Anabaptists of the late $19^{\text {th }}$ century. What most Mennonites in North America saw as the "Great Awakening" looked like, to the leaders of the Pure Church Movement, a great apostasy, a falling away from the principles of Christ. But, unlike the opposite side of the conflict (that of the Old Order groups), the leaders of the Pure Church Movement did not deny that revival was necessary. They recognized that "dead traditionalism” had nearly ruined what was left of Anabaptism in North America, and that new life in Christ was needed. They concurred with the assessments of the Great Awakening and shared its revivalistic fervor; only, the revival of the Pure Church Movement struck out in the exact opposite direction. Instead of departing from early Anabaptist teaching and example, it headed straight back into it.

Certain characteristics apply to most or all of the Pure Church groups today. These will be explained here prior to a detailed history of the groups.

\section{Religious Ideals and Practices}

All Pure Churches hold the Scriptures and early Anabaptist writings in the highest regard. All of them practice a highly developed church order with a discipline that is severe, frequently used, and followed by avoidance (shunning) that is total. All of them keep their fellowship pure by avoiding social interchange with other churches and fellowships they deem apostate-nearly all groups refusing to attend any worship service, including the funerals or weddings of family members, outside the group. In some groups, this separation from others remains total, members abstaining from as much as visiting the homes of non-members, even of their immediate family. In others, it has mellowed somewhat over the last half of the $20^{\text {th }}$ century.

The radical Pure Churches, unlike the Old Order, have not held to a fixed standard. Instead, they have made frequent and drastic changes throughout their history, if they felt it would bring them closer to early Anabaptism and the principles of Scripture. The Church must be free, it is believed among them, to follow the Spirit of Christ at all times. 
Unlike many Old Order groups, the radical Pure Churches focus on personal repentance, spiritual life, and accountability_single young people, husbands without their wives, and vice versa, having to answer for their conduct, frequently getting put out or taken back into fellowship on their own. All of the radical Pure Churches have taken a clear stand against the use of tobacco and questionable courtship practices. All men from their adolescence wear beards and clothing styles in general have moved from modest to drastically conservative. Church members, including the young people, greet one another with the "hand and kiss," and the words Der Friede sei mit uns (Peace be with us). Today, nearly all groups use horse drawn vehicles and most avoid automobiles as well, except when governed by the church (e.g. Lobelville, TN, has appointed drivers). Most keep electricity out of their homes. Among the Pure Churches are some of the most primitive lifestyles, comparable to the strictest Amish and Old Colony Mennonites.

Not static but outward looking, mission-minded, and adventurous, members of the radical Pure Churches have pioneered many settlements in North, Central, and South America. One recent example of their intrepid nature being the interaction of people from the tropical rainforest of Belize (Barton Creek) helping to build a new community in the bush of northern Ontario (Algoma Orthodox Mennonite), altogether without modern technology.

Not missionary success, however, but standing faithfully for the truth-even if one must do so alone- - has been the vision and goal of the radical Pure Churches. This, at times, has had a shattering effect on their membership. Families or even individuals within the movement have often chosen to remain without fellowship for many years rather than compromise on minor issues. Total dedication to their cause also tended to give all the emerging groups a tunnel vision that kept them from profitable interaction one with another-a situation that has begun to change in recent years.

\section{Occupations and Education}

Members of the radical Pure Churches do not hold jobs with non-members or work without the boundaries of the group. This, combined with their high birth rate, creates a vast pool of free or virtually free labor among them, greatly contributing to their material well-being. Entire groups continually work together to buy more farmland, often in large tracts, so all families can have land on which to provide for themselves. The sale of fresh produce and handcrafts, maple syrup in Canada, sorghum molasses in the southern United States, or citrus fruits and melons in Belize and Paraguay brings in the main part of the groups' income-also through creatively managed colony co-operatives.

Children in all radical Pure Church communities get educated by their own teachers in their own schools. During the 1960s, the Orthodox Mennonites in Canada contributed in a major way to obtaining parochial school legislation for all conservative Anabaptists in the country. 


\section{Population and Migration}

Based on the account of David incurring God's displeasure by numbering the Israelites (1 Chronicles 21), most groups within the Pure Church Movement do not feel comfortable with church statistics. Out of respect for that position, no individual statistics are given in this article but the entire movement included well over 5,000 people by 2010 .

Regarding retention, the ratio of young people staying in the church fellowship of their parents is nothing short of phenomenal. From the 1950s to 2010, for instance, the Orthodox Mennonites, by now including hundreds of families, have not had any young person leaving home or going to the world.

In terms of migration, Pure Church members, despite transportation restrictions, are highly mobile. Nearly all extended families have relocated at least once, some of them many times. They have not been hesitant to settle remote places, including wildernesses in Belize and Paraguay, and to avoid airplanes when conducting this international travel.

\section{Impact on Other Plain Anabaptist Movements}

The Pure Church Movement has both used and produced an important body of literature, centered on the writings of the early Anabaptists and early American Mennonite authors such as Heinrich Funk, Benjamin Eby, and Christian Burkholder. But writers within the movement, such as David Hoover, John W. Martin, John Dan Wenger, Titus Hoover, Abraham Hoover, Anson Hoover, Frederick J. Schrock, Amos Sherk, Elmo Stoll, and Bryce Geiser have contributed many more significant works. Through its widely disseminated literature and through its radical witness, the Pure Church Movement has impacted virtually all Old Order Mennonite and Amish communities. Its challenge, or the challenge to keep their most dedicated members from getting drawn into it, has moved Old Order leaders throughout North America to work on modest reforms.

\section{Distinctiveness from Other Plain Anabaptist Movements}

A common mistake by recent historians has been to describe the radical Pure Churches as individual Old Order groups. Even though they have maintained their autonomy, they by no means developed individually. They grew and now function, not exactly together, but constantly around one another. What one of them does has had a way of affecting the rest.

The dynamics of the Old Order groups in North America-Mennonites, Brethren, Amish, and Hutterites-are not those of the radical Pure Churches. Old Order groups tend to be sedentary, stable, and dedicated to the preservation of the status quo. Tradition holds weight when evaluating practice, because tradition stabilizes the church, whereas rapid change threatens to weaken the church and expose it to worldly influence. The radical Pure Churches, on the other hand, have as their goal not to guard the present but to recapture the past; they are ready to make 
sweeping changes in that direction, usually realizing stricter practices than Old Orders, or at least combinations of practices that, bundled together, may make little sense to Old Orders.

The Pure Church is also distinctive from progressive revivalist movements that use outside ideas to revise Old Order structures. These include not just denominations that left the Old Order such as Beachy and related Amish-Mennonites, the Remnant (i.e. "Charity") churches, and many conservative Mennonites, but also unaffiliated, non-denominational fellowships and pan-denominational organizations such as Anabaptist Identity Conference, “Kingdom”-type organizations, and Christian Aid Ministries. These revivalist groups loosen the screws on church structure in order to import new currents, especially currents from socially conservative American Christian thought. They are basically tired of the old grind-the tiresome traditional way - that never worked very well in their estimation. They tend to be fluid, open-minded, and restless. Everything they accomplish leads toward more and more acculturation and more links with mainstream evangelicalism, which inevitably carries them further and further away from Anabaptist thought and practice. Members in these movements, who used to be truly nonconformed, are slowly_or rapidly_turning into something else.

\section{Groups in the Pure Church Movement}

The principal groups ${ }^{1}$ to have become involved one with another, to have merged or influenced one another to create what we here identify as the Pure Church Movement are the following. Though this list is presented in a roughly chronological order, the timeline and effects of one movement upon another are multidimensional. Where another group is mentioned in one group's description, the name is in bold letters so it can be easily identified and referenced, if need be. Most of these groups are now extinct; those still extant today as a Pure Church group are marked with an asterisk.

\section{The Reformed Amish Christian Church (Tennessee / Pennsylvania) [1890s / 1937- 1952]}

The Amish Christian Church is a key early group within the Pure Church Movement established in Adams County, Indiana, during the 1890s under the leadership of Bishop David Schwartz. Composed of both Amish and Mennonite families speaking the Emmentaler Swiss dialect, the group absorbed a few members of a radical Amish group led by Noah T. Schrock that had settled near Phoenix, Arizona. Following David Schwartz's lead, the group quickly came to see itself as the sole surviving remnant of pure Christianity, the only Anabaptist group to stand in a direct line of Apostolic Succession - thereby in a position to administer valid Christian baptism. During its first 50 years, the Amish Christian Church passed through a period of drastic changes, during which nearly all vestiges of Amish tradition and lifestyle disappeared: members drove automobiles, used electricity in their homes, discarded the woman's headship veiling, and had fashionable hairstyles. In 1937, the most conservative core members of the group, calling themselves the Reformed Amish Christian Church, moved to Lawrence County, Tennessee. From 
there, they moved as a group of 65 people, in 1952, to Snyder County, Pennsylvania, where they merged with the Titus Hoover Group, bringing with them the concepts of Apostolic Succession, true baptism, and Rechtgläubigkeit (orthodoxy). This merger brought them back into a drastically simple lifestyle: no combustion engines, no appliances, and certainly no motor vehicles to get from place to place. It also led them into fruitful contact with the Elmira Prophetic Mission and the fledgling Orthodox Mennonite community in Ontario, resulting in a number of members from there joining the merged groups in Pennsylvania. A second merger occurred with a Swiss Amish group from Hohenwald, Tennessee, in 1954, while families of German Baptist and Old Order Mennonite background (both Canadian and American) moved in during the 1950s, along with a number of Russian Mennonites from Laird, Saskatchewan, in 1963. From Pennsylvania, members of all these backgrounds moved to Muddy Pond, Tennessee, in 1965, and from there (as also from Pennsylvania) to Scottsville, Kentucky, in the late 1970s. Several hundred descendants of the Amish Christian families, some still speaking their Emmentaler Swiss dialect, survive in the Scottsville Mennonite Community with its branches today.

\section{The Daniel Brubacher Group (Ontario) [1911-c.1952]}

The Daniel Brubacher Group formed in 1911 when Daniel Brubacher, an Old Order minister of Waterloo County, Ontario, began to hold meetings in his home. In 1917, Brubacher and his followers joined the newly organized David Martin Group. A year later, Brubacher was ordained bishop of the merged groups, but in 1920, he left the union, but then died in 1921. The flock diminished greatly but continued to hold meetings at least until 1952, when Menno Brubacher died, leaving only his wife, three daughters, and Christina Metzger in the group.

Several hundred descendants of Daniel Brubacher and his followers survive in the David Martin and Orthodox Mennonite communities today.

\section{The David Martin Group (Ontario)* [1917-present]}

The David Martin Group left the South Peel Old Order Mennonite congregation, Wellington County, Ontario, in 1917. Distinguished by their zeal for the pure church, leaders of the group turned to early Anabaptist writings and quickly established an unusually rigid structure of accountability, order, and discipline. After a short-lived merger with the Daniel Brubacher Group, Enoch Horst was ordained bishop in 1921. When Horst left with a small group in 1924, David Martin became bishop. In 1946, he led his group into a merger with the Paul Shank Group from Dayton, Virginia, but during the following decade, beginning in 1953, around one hundred people withdrew from David Martin's oversight to become the core members of what are now the Orthodox Mennonite Communities. The David Martin Group continued to flourish, although in a totally independent manner, and large congregations met in five places of worship by 2010. 


\section{The Rainham Group (Ontario)}

Dissatisfied with what they felt was a worldward drift in the Old Order Mennonite (Markham-Waterloo Conference) congregations to which they belonged, several families from the Rainham and South Cayuga congregations in Haldimand County, Ontario, joined the emerging David Martin Group from 1917 to 1922. Last to join was Deacon Franklin Housser (1859-1933) of the South Cayuga congregation, in 1930. The Hoover and Sherk families from Rainham came to play an important role, not only in the David Martin Group but in the Orthodox Mennonite Communities, as well as in the merged Amish Christian and Titus Hoover groups in Pennsylvania. Menno Hoover (1889-1983) led in the formation of the first Orthodox Mennonite Community in 1953. His brother-in-law Menno Sauder operated the Elmira Prophetic Mission, at Elmira, Ontario, from the 1940s through the 1970s. Abraham Hoover (1926-1970) was instrumental in the formation of the Muddy Pond Group in Tennessee. Anson Hoover (1920-2008) led a group of his own during the 1970s. Well over a thousand descendants of the Rainham families belong to the David Martin Group, the Orthodox Mennonite, and Barton Creek communities today.

\section{The Enoch Horst Group (Ontario) [1924-1990s]}

The Enoch Horst Group formed in 1924 when Bishop Enoch Horst (1881-1955), Minister Amos Bearinger, and a small number of followers separated themselves from the David Martin Group in Waterloo County, Ontario. Some members scattered, while others, during the 1950s, found unity with the group under Jonas Nolt at Mammoth Springs, Arkansas. These members later joined those of Amish Christian and Orthodox Mennonite background who left the Titus Hoover Group to settle in Muddy Pond, Tennessee. Known for its radical teaching on church purity, the remnant of the group that remained in Canada dwindled until its last members died at Wallenstein, Ontario, in the 1990s. Amos Bearinger himself eventually returned to the Old Order Mennonites.

\section{The Kitchener House Churches (Ontario)}

In September 1929, five members, including Elizabeth (Lizzie) Bauman (1909-2002), separated from the David Martin Group. A year later she rejoined the group, but left again soon after. Convinced of her need to serve Christ in total detachment from earthly things, Lizzie Bauman felt compelled by the Holy Spirit to go out with the message of Christ, to witness to all people of his saving power, and to serve the poor. With Amanda Eby, another itinerant worker, she found her place among immigrant and low-income families in the city of Kitchener, Ontario. After a Mennonite-run shelter, the "House of Friendship to All Nations" opened in Kitchener in 1938, her area of service widened. For Lizzie Bauman, pure doctrine, the Pure Church, was not to be found in sectarian isolation but in Christ-like service to the poor. Yet her work in the city kept bringing her friends, seekers of many nationalities, together in house fellowships - the Kitchener House Churches, as they came to be called. It also brought them into contact, through 
her, with bishop Elam S. Martin (her uncle) of the Orthodox Mennonites; the family of Amos Bearinger (another uncle), who had been a minister in the Enoch Horst Group; minister Anson Hoover of the Orthodox Mennonites, who lived across the road from the Bearingers and took a keen interest in the House of Friendship; and the Elmira Prophetic Mission. Above all, Lizzie Bauman's contact and influence on her brother, Daniel Bauman (married to Anson Hoover's sister), had far-reaching implications. In the mid-1950s, Daniel had joined the merged Amish Christian and Titus Hoover groups in Pennsylvania. But a spiritual awakening at Muddy Pond, Tennessee-a community he had been instrumental in establishing-led him to the group from St. Joe, Arkansas, then establishing themselves at Pilgrimage Valley in Belize. In the mid1960s, Lizzie Bauman with her house fellowship also traveled to Belize with hopes of settling there. Trusting God to supply them with the necessary funds for the enterprise, they got to Miami, Florida, before U.S. officials detained them and then deported them to Canada. Lizzie Bauman continued her work in the city of Kitchener almost until her death in $2002{ }^{2}$

\section{The Elmira Prophetic Mission (Ontario)}

The Elmira Prophetic Mission, a book selling and publishing establishment operated by Menno Sauder (1890-1972) on his farm east of Elmira, Ontario, contributed in a major way to the Pure Church Movement. Although Menno Sauder, married to a sister of Menno Hoover of the Rainham Group, had close ties with all the Pure Church groups, he declined to become a communicant member of any. Having found the Lord through a supernatural experience while driving to town with his horse and wagon in the 1930s, Sauder dedicated his life to what he believed was his call from God-that of warning the $20^{\text {th }}$ century Church of pernicious plots for its destruction and to point all believers back to what they had lost. Of particular concern to Sauder was John Nelson Darby’s concept of Dispensationalism (premillennialism) that had profoundly impacted the Anabaptists of North America. This influence, Sauder correctly perceived, had entered through the $19^{\text {th }}$-century revivalism of the Evangelical movement. Consequently, he saw in all these influences (Dispensationalism, revivalism, and Evangelicalism) a force that undermined and militated against the teachings of non-violent Anabaptism. To counteract it, he promoted, translated, and in some cases reprinted the writings of European Anabaptists like Jan Schabalie, Pieter Pietersz, Dirk Philips, and Pieter Jansz Twisck, along with the writings of North American Anabaptists such as Henry Funk, Benjamin Eby, Abraham Blosser, Christian Burkholder, and Peter Burkholder. Thanks to Menno Sauder's scholarship, his untiring energy, and constant travels through well over 50 years, the Elmira Prophetic Mission became a channel through which the vision of earlier Anabaptists entered the Pure Church Movement. Of particular importance was his connection with John W. Martin, printer of St. Joe, Arkansas, and with his two nephews, Anson Hoover of the Orthodox Mennonites and Abraham Hoover of the merged Amish Christian and Titus Hoover groups. 


\section{The Paul Shank Group (Virginia) [c.1946-c.1952]}

After a troubled ordination among the Old Order Mennonites in Virginia, presided over by Bishop John Dan Wenger (1871-1967), a group of members under the leadership of minister Paul Shank withdrew and merged, in 1946, with the David Martin Group in Canada. Six years later, another troubled ordination caused Wenger himself to withdraw from the Virginia Old Order Mennonites. This, combined with the fact that the David Martin Group was undergoing a division (the emerging of the Orthodox Mennonite community), led Paul Shank and his followers to return to the Virginia Old Order Mennonites, now under the leadership of Russell Cline. Separating again, a number of the Shank families became charter members of the Pleasant Valley Mennonite Church (Nationwide Fellowship) founded in 1977, at Dayton, Virginia.

\section{The Reidenbach Mennonites (Pennsylvania)* [1942]}

The Reidenbach Mennonites separated from the Groffdale Old Order Mennonites of Lancaster, County, Pennsylvania, during the World War II. Seeking a more humble, earnest way of life-as well as objecting to any form of alternative service during wartime-a group of families including John W. and Fannie Martin (see St. Joe, Arkansas, Group) began to look for other alternatives. After the Martins left for Mexico in 1942, the rest of the group drew together under the leadership of David Hoover and, six years later, built a meetinghouse at the Reidenbach store. Immediately after his separation from the Groffdale Old Order people, David Hoover took up contact with the David Martin Group in Canada. Then, in the early 1950s, the Orthodox Mennonites, having separated from David Martin, investigated a merger with him. Instead of that happening, David Hoover's co-worker, minister Peter Nolt, with a number of families, left the Reidenbach Group to unite with the Orthodox Mennonites in 1958 (see Peter Nolt Group). In 1963, the Noah Brubacher Group in Canada, formerly associated with bishop John Dan Wenger in Virginia, joined the Reidenbach Group. They left in 1965 and merged with the Orthodox Mennonites in 1967. After a series of divisions among the Reidenbach people during the last decades of the $20^{\text {th }}$ century, some of its members have regrouped both within and outside Lancaster County, including in Montour and Northumberland Counties, Pennsylvania, and in Christian County, Kentucky

\section{The St. Joe Group (Arkansas) [1950-1966]}

The longing for church purity that brought a number of Groffdale Old Order Mennonites to form the Reidenbach Group in Pennsylvania, took one family from their midst in a radically different direction. Sharing the concerns of what became the Reidenbach people, and in close fellowship with them, John W. Martin (1909-1963) left with his family for Mexico in 1942. After some time among the Old Colony Mennonites in Chihuahua State, the Martins settled at Rascón, in the Mexican state of Tamaulipas. Five families, including the Phineas Borntrager family of Amish background, joined the Martins there. A series of floods, death through malaria, and other adversities drove them back to the United States by the end of the war. Following two years in 
Snyder County, Pennsylvania (among those that came to form the Titus Hoover Group), the Martins moved to a new Amish settlement at Hohenwald, Tennessee, with the Phineas Borntrager family, in 1947. Three years later, the Martins and several Amish families, including that of Minister Albert Stoll (1905-1992), originally from Daviess County, Indiana, settled at St. Joe, Arkansas. Jonas Nolt, with a number of members from the Titus Hoover Group in Snyder County, Pennsylvania, joined them in 1955, only to leave them six years later to join the settlement at Mammoth Springs, Arkansas. During a nearly fatal bout with asthma in the early 1950s, John W. Martin promised the Lord to spend the rest of his life warning the faithful of the perils of apostasy, urging them to stick to the narrow way of Christ. To better accomplish this, he bought a printing press and began to publish both Anabaptist and original writings, including the periodical The Narrow Way. This immediately brought him into productive contact and interchange with the Elmira Prophetic Mission in Canada, the merged Amish Christian and Titus Hoover groups in Pennsylvania, and the Orthodox Mennonites after 1953. During the late 1950s, the John W. Martin family spent more time in Mexico and in North Carolina, but always returned again to St. Joe. Three years after his death in 1963, John W. Martin’s family with the Albert Stoll family and others moved to Belize in Central America, establishing the Pilgrimage Valley Mennonite Community, and the settlement at St. Joe ceased to exist. Many descendants of its founding families now live at Barton Creek in Belize, at Finger and Cane Creek in Tennessee, and at the Scottsville Mennonite Community in Kentucky.

\section{The Hohenwald Amish Group (Tennessee) [1947-1955 / 1955-1990]}

In 1947, another group of Emmentaler-Swiss Amish families left Adams County, Indiana, to start a new community at Hohenwald, Lewis County, Tennessee. The Phineas Borntrager family that had lived in Mexico (see St. Joe, Arkansas Group) and soon afterward the John W. Martin family joined them. After the Martins moved on to St. Joe, Arkansas, the rest of the Hohenwald group, under the leadership of minister Jerry Troyer (1917-2001) sought unity with the merged Amish Christian and Titus Hoover groups in Snyder County, Pennsylvania. Relocating as a group to Snyder County in 1955, they settled just south of the rest, near the village of Meiserville. By 1958, this merger fell through, and the group continued as the Mt. Pleasant Mills Amish. But a number of Hohenwald young people had married into the Snyder County group and stayed with it. Some of them left with the people that moved to Muddy Pond, Tennessee in 1965, and moved on from there to Lynchburg, Tennessee, in 1970. There, they helped to establish an ultra-conservative, car-driving Mennonite Church, operating on Pure Church principles, under the leadership of bishops Paul and Raymond Horst. Minister Jerry Troyer moved to the Pilgrimage Valley Community in Belize, in the mid-1960s, from there back to Cane Creek near Lobelville, Tennessee in the 1970s, and finally to Muddy Pond, Tennessee where he died, a member of the Pilgrim Christian Fellowship (Remnant Movement) in 2001. The Mt. Pleasant Mills Amish settlement went extinct in 1990 


\section{The Titus Hoover Group (Pennsylvania) [1949-1995]}

Seeking renewal and a return to the purity of the first Anabaptist fellowships, a number of Old Order Mennonite families from Lancaster County, relocated to Snyder County, Pennsylvania, to join a remnant of the Stauffer Mennonite Church - the Aaron Martin Group-in the late 1940s. One of these men, Jonas Nolt, was ordained a deacon by Aaron Martin but left that group with the others from Lancaster in 1949. Together, the Lancaster families living in Snyder County began a new fellowship pattern, as closely as they knew how, on the teachings of Christ as exemplified by the first Anabaptists. This quickly drew more seekers from the Stauffer and Old Order Mennonite groups into their circle. Titus Hoover, of Old Order background, who had also spent time with the Stauffer Mennonites in Snyder County, became bishop of the new group, by election, around 1950. His active search for the pure Church brought him into contact with the Reformed Amish Christian Church, then living in Tennessee. A merger of the two groups took place in 1952, with the Amish Christians - constituting well over half of the total membership_relocating to Pennsylvania. In 1954, Jonas Nolt, with a number of members, left the merged group to join the group at St. Joe, Arkansas. During the mid-1950s Titus Hoover, with Enoch Habegger and David Graber-former Amish Christian Church leaders—-travelled to Canada to effect another merger with the Orthodox Mennonites. While full unity did not materialize-only some of the Canadian group moved to Pennsylvania and joined the fellowship —a long-standing productive relationship began that has continued between the Orthodox Mennonites and the Scottsville Mennonite communities for more than 60 years. In 1963, nearly all members — including those of Amish Christian, Old Order Amish, Old Order Mennonite, Orthodox Mennonite, and Russian Mennonite background — separated from Titus Hoover under the leadership of Minister Noah Hoover, along with Enoch Habegger and David Graber. After further division and reuniting, they became what is now the Scottsville Mennonite Community in Allen County, Kentucky. In the late 1960s, Titus Hoover became instrumental in establishing the upper Barton Creek Mennonite Community in Belize. Membership in his group in Snyder County, Pennsylvania, dwindled until 1995 when remaining members left him.

\section{The John Dan Wenger Group (Virginia)* [1952-present]}

The John Dan Wenger Group, after separation from the Virginia Old Order Mennonites in 1952, sought unity with the emerging Orthodox Mennonite Community in Canada. But unity could not be established due to the Canadians' looser interpretation of the ministerial office (ordaining men without bishops present). Because of this, Wenger could not accept the Canadians' baptism as valid, but he received into his communion another small group in Waterloo County, Ontario, a branch of the Old Order Mennonites, under the leadership of Noah Brubacher. Bishop Wenger ordained Noah Brubacher to the ministry. Two years later, most of the Noah Brubacher Group along with one Virginian member, Abram Rohrer, left bishop Wenger. They joined the Reidenbach Group in Pennsylvania, only to leave them in turn and merge with the Orthodox Mennonites by 1967. For around ten years following this date, Orthodox Mennonite ministers from Canada held worship and communion meetings at the 
Abram Rohrer home near Dayton, Virginia. The remainder of the John Dan Wenger group continued with their bishop.

\section{The Orthodox Mennonite Community (Ontario)* [1953-present]}

In 1953, a number of members, all descended from or married into the Rainham Group left the David Martin Group in Waterloo County, Ontario, to become organized, over a period of time, as the Orthodox Mennonites. Immediate contact with the merged Amish Christian and Titus Hoover groups led to a number of members moving to Pennsylvania in the mid-1950s. Further contact with Old Colony Mennonites from Mexico brought several Plattdeutsch-speaking families from Durango and Chihuahua to Canada where they joined with the new group. Some of these families became instrumental in establishing the communities at Barton Creek, Belize, during the 1960s. In 1956 a minister, Elam S. Martin, from the David Martin Group, joined and took the responsibility of voller Diener (acting bishop) among the Orthodox, although not by ordination. In 1959, minister Peter Nolt with five families from the Reidenbach Mennonite Church in Pennsylvania, as well as deacon Samuel Horst with another 50 people from the David Martin Group, merged with the Orthodox. In 1967, another merger took place with the Noah Brubacher Group (formerly associated with John Dan Wenger and the Reidenbach Church). Steady contact with the merged Amish Christian and Titus Hoover groups continued, bringing further interchange of members along with ever more radical concepts on living out early Christian and Anabaptist ideals. In 1974, a group of members unwilling to make the adjustments separated under the leadership of minister Anson Hoover. In 1987, most of the various factions left in the Waterloo Region, including the extended Noah Brubacher family and three ministers from what remained of the Anson Hoover group, became reconciled and all moved to Huron County where they merged to become the re-established Orthodox Mennonite Church. Furthermore, in the late 1980s and into the 1990s, families from the Barton Creek and Reinfeld communities in Belize and Paraguay, along with over 150 people from the Ontario Old Order Mennonites, joined the Orthodox. These reconciliations and mergers brought unprecedented peace and spiritual prosperity that led in turn to numerous other mergers and brought many more seekers into the fold that quickly doubled, and soon quadrupled, in size. In 1997, a group of Old Order Mennonites in Christian and Casey Counties, Kentucky, merged with the Orthodox, followed by other groups of the same background in Trigg County, Kentucky, in 1998, and at Kinloss, Ontario, in 1999. Families remaining with the Phares S. Stauffer Group of Snyder County, Pennsylvania, likewise found unity with the Orthodox Mennonites. During the 1990s, members of the Canadian Orthodox Mennonite communities began to move into the Algoma Region of northern Ontario. In 2006, a group leaving their fellowship moved to Gladstone, Manitoba, Canada. All told, the Orthodox Mennonites met for worship in nine locations, not all of them with meetinghouses, by 2010. A respectful relationship continues with the Scottsville Mennonite Community in Kentucky, along with its branches in Missouri, Tennessee, and Belize, (the main surviving body of the merged Amish Christian and Titus Hoover groups), as with the Barton Creek Mennonite Communities in Belize, Central America. 


\section{The Noah Brubacher Group (Ontario) [c.1955-1967]}

During the 1950s another move for the purification of the Church swept through the Old Order Mennonites of Woolwich Township, in Ontario’s Grand River Valley. Noah Brubacher, with several supporting families, began to meet in his home north of the village of Conestogo. Brubacher's next-door neighbor, Joshua Bauman (brother-in-law to Brubacher's brother-in-law and closest supporter) shared many of the new group's concerns. When unity among them proved impossible, Bauman and his family moved to Pennsylvania, joining the merged Amish Christian and Titus Hoover groups, while the rest of the families merged with the John Dan Wenger Group in Virginia in 1959. After two years, during which bishop Wenger ordained Noah Brubacher to the ministry, the merger fell through. A few members of the Brubacher group moved to Virginia to stay with John Dan Wenger and his followers. A few joined the Orthodox Mennonites. The rest found their way into a short-lived unity with the Reidenbach Mennonite Church of Lancaster, County, Pennsylvania, from 1963-65. In 1967, what remained of the Noah Brubacher Group in Canada, including Minister Noah Brubacher himself, merged with the Orthodox Mennonite Community. This merger, for the adjustments it brought with it, led to a serious division among the Orthodox in 1974, when over half the members withdrew under the leadership of Anson Hoover. When Anson Hoover and a number of members attempted to return to the Orthodox in 1977, the circumstances surrounding Noah Brubacher's abrupt and unusual death led to a three-way division in 1980, in which Noah Brubacher's extended family and another small group got separated from the main group of Orthodox Mennonites under Bishops Elam S. Martin and John Sherk. At the same time, and beginning in the late 1970s, the Orthodox Mennonites, under John Sherk’s leadership, relocated farther to the northwest, to Gorrie and Wroxeter areas (a former Amish settlement) in Huron County, Ontario. In 1987, the Noah Brubacher extended family reconciled with the Orthodox Mennonite Church and followed them in this move.

\section{The Mammoth Springs Group (Arkansas) [1961-1979]}

In 1958, German Baptist Minister Benjamin Lavy (1916-1979), with a small number of members from Camden, Indiana, moved to Snyder County, Pennsylvania, to find fellowship with the merged Amish Christian and Titus Hoover groups. In 1961, he relocated to Mammoth Springs, in Fulton County, Arkansas, where he was joined by Jonas Nolt, one of the founders of the Titus Hoover Group, who moved in with his family from St. Joe, Arkansas. Nolt, who served as a minister at Mammoth Springs, got kicked by a horse and died within the settlement's first year. But other families of both Amish and Mennonite background moved in, including two from Canada (see Enoch Horst Group). Contact with Canada-the Elmira Prophetic Mission and the Orthodox Mennonites - continued. After some from Mammoth Springs (the Horsts) moved to Muddy Pond, Tennessee, in 1968, the remaining families parted ways. Minister Paul Lavy with a group of members moved to Cane Creek, near Lobelville, Tennessee, to begin a new community in 1971. The Noah Stutzman family, earlier from Canada, moved to Cedro Tú in Eastern Paraguay to begin a settlement there. They, as also the Henry Mast family from 
Mammoth Springs, later united with the Scottsville Mennonite Community in Kentucky. Minister Benjamin Lavy resumed his membership and ministry among the German Baptists who for some time, during the 1970s, helped him rebuild the church community at Mammoth Springs. But after Lavy's death, in 1979, the last families moved away and the work came to a close.

\section{The Peter Nolt Group (Missouri)* [1956-present]}

The Peter Nolt Group left the Reidenbach Mennonites in 1956. They joined the Orthodox Mennonites in 1957 but left again in 1959. In 1966, the Aaron Reiff and Phares Martin families left Peter Nolt, reducing the size of the already small group. In 1972, Peter Nolt had plans to move the group to Versailles, Missouri, where other Old Order Mennonites from Pennsylvania were moving. However, he had a heart attack and died suddenly. His small group decided to move anyways, though without an ordained leader.

\section{The Noah Hoover Group [1963] and the Scottsville Mennonite Community (Kentucky)* [1978-present]}

After separating from Titus Hoover and those who continued to work with him in Snyder, County, Pennsylvania in 1964, a large church of Amish Christian, Russian Mennonite, Stauffer, Orthodox, and Old Order Mennonite background remained under the leadership of Ministers Noah Hoover, Enoch Habegger, and David Graber. The question of true baptism (Apostolic Succession) plagued the group, however, and in a general state of repentance, revival, and spiritual upheaval, the group made a new start, some staying in Snyder County, Pennsylvania, under the leadership of David Graber and Noah Hoover, others (mainly the younger more radical element) founding a new community at Muddy Pond, Tennessee. In 1967, most of the Tennessee and Snyder County people got reunited, although families continued to leave one by one over the following ten years. Beginning in 1978 and lasting into the early 1980s, what was left of both groups made a new start by migrating to Scottsville, Kentucky. There, the new community prospered and, 40 years later, continues to grow steadily. Shortly after the new start at Scottsville, the church merged with the upper Barton Creek community in Belize, consisting of Kleine Gemeinde Mennonites, Old Colony Mennonites, and a good number of members formerly of Belize's Pilgrimage Valley Community (earlier from St Joe, Arkansas). In 1994, a small group from Scottsville, led by Levi Shirk and Jonathan Habegger, formed a new community at Holland, ten miles east of Scottsville, Kentucky, in co-operation with Elmo Stoll and the Christian Communities at Cookeville, Tennessee. The group survives, but since 1999, is back in full fellowship with Scottsville. In 1993, another branch community began at Rich Hill in Bates County, Missouri. By 2018, these so-called "Hoover Mennonites” claimed four other more recently established communities, two in Missouri, one in Ohio, and one in Tennessee. Friendly relationships continue with the Orthodox Mennonites, by now established in neighboring Trigg and Christian Counties, Kentucky, as with the lower Barton Creek community and its branches in Belize. A good relationship also exists between the church at 
Scottsville and the re-established Christian Community at Caneyville, Grayson County, Kentucky.

\section{The Laird Group (Saskatchewan)}

In the late 1890s, the Peter Becker and Johann Schartner families, former members of the Church of God in Christ, Mennonite (Holdeman) church, moved to the Waldheim (Laird) district on the far northern edge of the settled parts of Saskatchewan. Other very conservative Plattdeutsch-speaking Mennonites joined them, including some connected with the Bergthaler migration to Paraguay in the 1920s but who returned, disappointed with that group's failure to recapture the Church's original purity. Internal difficulties plagued the small group at Laird, near the point of disintegration by the time it made contact with the Canadian Orthodox Mennonites that had moved south to join the merged Amish Christian and Titus Hoover Groups in Pennsylvania. Several families from Laird followed suit and likewise moved to Pennsylvania where a few members joined the move to Muddy Pond, Tennessee, in 1965, and the rest stayed with Titus Hoover until his group disbanded in 1995. Limited contact between the remaining Mennonites from Laird, the Elmira Prophetic Mission, and the Orthodox Mennonites in Canada continued through the 1960s.

\section{The Muddy Pond Community (Tennessee) [1965-1982]}

The Muddy Pond Community, set in the forested highlands of Overton County, Tennessee, took shape when 14 families of Amish Christian, Orthodox Mennonite, LairdSaskatchewan, and Hohenau Amish backgrounds settled there, along with the Joshua Bauman family (see Noah Brubacher Group) from Canada, in 1965. While most of these original families had belonged to the Titus Hoover Group in Snyder, County, Pennsylvania, they set out on their own to build a church securely anchored in the Apostolic Succession and true baptism they believed was theirs through the Amish Christian Church. During the first year in Tennessee, Joshua Bauman and a small group of families separated from the rest at Muddy Pond. The John Oberholtzer family (see Jacob Oberholtzer Group) also separated and conducted an independent work at Muddy Pond until they moved to Pilgrimage Valley, Belize. By 1967 the main group at Muddy Pond, under the leadership of Richard Habegger, stood once more in full fellowship with those left behind in Snyder County (those who had regrouped under Noah Hoover). After Richard Habegger died in 1982, nearly all remaining members of the group at Muddy Pond moved to Kentucky, where they joined the ones from Snyder County (those with Noah Hoover) in what became the Scottsville Mennonite Community. The rest of the members scattered, a few having moved back to the Orthodox Mennonites in Canada, a few joining the Church of God in Christ, Mennonite (Holdeman), and some choosing to remain in Muddy Pond but with no affiliation. In 1998, some of them, along with families moving in, organized Pilgrim Christian Fellowship, a Remnant-type (Charity) church. 


\section{The Joshua Bauman Group (Tennessee) [1965-c.2005]}

Separating from the rest of the families that settled at Muddy Pond, Tennessee, the Joshua Bauman family from Canada (see Noah Brubacher Group) and a number of families of Amish Christian background began to hold separate meetings in 1965. Increasingly, after Ronald Reagan - a convert from Herbert Armstrong's Church of God-joined, the group departed from conventional Anabaptist teachings. This led most of its members to withdraw and establish the Cumberland Mountain Church of God in Christ, Mennonite (Holdeman) at Muddy Pond in 1971. Meetings continued in the Joshua Bauman home until his death circa 2005, by which time a number of his family had united with the Remnant Churches beginning in 1998, the evangelist Jerry Mawhorr being Joshua Bauman’s son-in-law.

\section{The Pilgrimage Valley Community (Belize) [1966-c.1972]}

The Pilgrimage Valley Community, just south of the large Spanish Lookout Kleine Gemeinde Mennonite Colony, near San Ignacio (Cayo), Belize, got established in 1966 when the extended Albert Stoll and John W. Martin families (Martin no longer living) moved in from St. Joe, Arkansas. Others followed in short order, including minister Jerry Troyer, originally of the Hohenwald Amish group, later of the merged Amish Christian and Titus Hoover groups, plus former members of the Mammoth Springs, Orthodox Mennonite, Muddy Pond, Old Order Mennonite, and Amish groups. At its beginning, the community’s radical simplicity in lifestyle and high standard of ethics held the promise of achieving all the Pure Church Movement had hoped to attain. But by the early 1970s most of the families had moved or were moving to other locations, mainly to the upper Barton Creek settlement nearby, to the Finger and Cane Creek communities in Tennessee, and eventually to the Scottsville Mennonite Community in Kentucky. Minister Jerry Troyer died at Muddy Pond, Tennessee, in 2001, where he had joined the Pilgrim Christian Fellowship.

\section{The Upper and Lower Barton Creek Communities (Belize)* [1968-present / 1972-present]}

As the large General Conference Mennonite community at Mountain Lake, Minnesota, increasingly lost its Anabaptist distinctives during the first decades of the twentieth century, a number of families held back or began to look for other alternatives. One of them, the Penner family, of the Bruderthal neighborhood, north of the village of Mountain Lake (an area particularly affected by late $19^{\text {th }}$ century revivalism) moved north to Canada in the 1920 s and from there to Durango, Mexico, in the 1930s, becoming members of the Old Colony Mennonite Church. Many of the next generation of the extended Penner family, still seeking greater church purity and a return to the early Anabaptist way, moved to the new Shipyard Old Colony settlement, near Orange Walk, Belize in 1958. There, they were joined in 1960 by the Peter Wiens family, likewise with roots in Durango, Mexico, who had moved to Canada and become members of the Orthodox Mennonites. In 1959, with the help of the Mennonites from Canada, 
Anson Hoover in particular, Peter Wiens and a small group of families settled at Dolores in far southern Belize. When that settlement failed, they joined the Penners at Orange Walk, where they were joined in the mid-1960s by the extended Jakob Guenther family, who had sought renewal in Durango, Mexico, but also ended up living among the Orthodox Mennonites in Canada. In 1968, the extended Penner, Guenther, and other families from Orange Walk merged with a group of Kleine Gemeinde and Sommerfelder background that had left the Spanish Lookout Colony in Belize's Cayo District in 1966. A radical attempt at restoring the pure church, they had moved into the virgin rainforest along Lower Barton Creek, further south in the Cayo District. In 1969, Titus Hoover from Snyder County, Pennsylvania, visited Belize, spending time at Pilgrimage Valley and baptizing numerous families at Lower Barton Creek. In the ensuing revival of radical Pure Church teaching and very simple living, the Friesens, Dycks, Harders, and others from Lower Barton Creek helped the Martins, Stolls, and Sherks from Pilgrimage Valley establish a new community in Upper Barton Creek. More Old Colony Mennonite families from Mexico kept moving in. During the late 1970s, a group from Barton Creek established the new Reinfeld Community in eastern Paraguay. In the 1990s, a branch community of Barton Creek began at Pine Hill in Belize’s Toledo District, and in 2009 another one near Middlesex in Stann Creek. A close relationship and considerable interchange of members has continued between Lower Barton Creek, Pine Hill, and the Canadian Orthodox Mennonite Communities. Some from Upper Barton Creek moved to Cane Creek at Lobelville, Tennessee, during the 1980s. The rest in Upper Barton Creek, under the leadership of John Shirk and Titus Martin, found unity with the Scottsville Mennonite Community in Kentucky c.1985. Altogether, the Barton Creek communities have prospered, both materially and spiritually, and are growing at a steady pace. Contrary to their liking, they have drawn considerable media attention, in particular a widely broadcasted "Dr. Phil” show in 2006. The communities as a whole, with a remarkably conglomerate membership, including native Belizeans, use primarily the German language in its schools and worship meetings.

\section{The Cedro Tú Community (Paraguay) [1967-2007]}

The Cedro Tú Community, Caaguazú State, Paraguay, took shape when in 1967 a group of four families from the Paoli, IN, Amish community settled there. The Noah Stutzman family, formerly of Mammoth Springs in Arkansas, joined them c.1969. Situated about $20 \mathrm{~km}$ (12 miles) north of the Bergthal Mennonite Colony, a 14,000 hectare (34,580 acre) tract of land had become available when a Mennonite timber dealer, Johann Janzen, opened it for settlement in the late 1960s. Most of this was taken up by Plattdeutsch-speaking families from Mexico, Brazil, Uruguay, Bolivia, Germany, North America, and Russia. The group experienced a division in the early 1970s that lasted until 1979, when reconciliation was made. In 1980, Noah Stutzman moved to the Scottsville Mennonite Community. Several years later, those remaining moved deeper into the wilderness, to La Belleza in 1988. But the community was without a minister and led informally by Amos Gingerich. Hence, they eventually sought fellowship with the Scottsville Mennonite Community in Kentucky. A few brothers from there, including Bishop David B. 
Hoover and Ellis Marzelin, as well as Isaak Fehr of Belize, made the epic journey from Kentucky to Paraguay by land in 1998 to achieve the desired unity-their sea passage on a small vessel from Panama to Colombia being particularly perilous. But shortly after their return, a faction withdrew from La Belleza, and by 2002, were established as a Beachy Amish-Mennonite church. Thus, the Scottsville leadership recommended that, due to the distance, families move to Upper Barton Creek, Belize, or Scottsville, Kentucky, which some did in 1999. Those remaining trickled out until none remained by 2007. The Pure Church movement here brought in a number of local converts, which brought much intermarriage. One notable achievement was the translation of portions of the Ausbund into Spanish.

\section{The Reinfeld Mennonite Community (Paraguay)* [c.1970-present]}

The Reinfeld Mennonite Community at San Ignacio, Misiones State, Paraguay, came from a radically conservative element among the Sommerfelder and Bergthaler people that moved to South America in 1948. Guided by the writings of previous elder Gerhard Wiebe (1827-1900), as by the writings of Pieter Pietersz and the early Anabaptists, they turned to a greatly simplified way of life, farming only with horses and living without electricity. The first families, including ministers Jakob Funk and David Klippenstein, settled at San Ignacio before 1970. Other families from both Bergthal and Sommerfeld joined the group. During the 1980s, they established a relationship with those from Lower Barton Creek who settled at Reinland / Campo Alto, Caaguazú State, Paraguay. During the 1990s, a number of families from San Ignacio, including those of the ministers David Klippenstein and Johann Wiebe, moved to Bolivia. Contacts with Lower Barton Creek in Belize continue, while a stable and steadily growing group of over 20 families appears to be prospering at Reinfeld, San Ignacio.

\section{Finger Christian Fellowship (Tennessee) [1977-present]}

The Finger Christian Fellowship in McNairy County, Tennessee, took shape within the Pure Church Movement. In 1969, the Victor Stoll and Harry Wanner families-who had been united with the merged Amish Christian and Titus Hoover groups in Snyder County, Pennsylvania - moved to the Pilgrimage Valley Community in Belize, led by Victor's father, Albert Stoll. In 1974, they left Belize to unite with a group of Amish background at Dover, Delaware. From there, in 1977, the Stoll and Wanner families moved to Finger, in McNairy County, Tennessee, with the Simon and Joseph Beachy and William Mast families a year later. Simon Beachy had been a minister among the Amish. As the community at Finger, Tennessee, increased in size (others from Pilgrimage Valley moving in), its members gradually eased their position on the use of modern technology. Motor vehicles and electricity came into common use, along with telephones, computers, and cameras. Simon Beachy, with a significant group of members, left for Cane Creek, at Lobelville, Tennessee, in the early 1970s. A number of members, including the Harry Wanner family, moved to Kentucky, where they found fellowship with the Scottsville Mennonite Communities. A Remnant-type congregation of over 30 families continued at Finger at least through 2010, although not as a Pure Church group. 


\section{Cane Creek Mennonite Community, Lobelville_-Believers in Christ (Tennessee)*}

The Cane Creek Mennonite Community at Lobelville, in Perry County, Tennessee, began with a number of families from Mammoth Springs, Arkansas moving in in 1971 under the leadership of Minister Paul Lavy (1940-1998). Joined soon afterward by minister Simon Beachy and a group of members from Finger, Tennessee, the Cane Creek Community rapidly multiplied with the influx of both Pennsylvania-German and Plattdeutsch-speaking families from Pilgrimage Valley and Barton Creek, as well as from North American plain backgrounds. The German Baptist element within the group—its name notwithstanding —was English-speaking. This, combined with the community's radical witness in simple living, attracted a significant number of seeking families from non-plain backgrounds that either joined the community or became active in its periphery. For some time the Christian Pilgrims (see below) frequented Cane Creek. In the 1990s, Michael and Debbie Pearl, with whom some from the community became united, began No Greater Joy Ministries, capitalizing on their proximity to Cane Creek and the bridge it provided for their literature into plain churches. The Church of God in Christ, Mennonites (Holdeman) founded the Pleasant View Mennonite Church within the community in 1985. In 1996, Minister Simon Beachy with a group of members relocated to Hestand, in Monroe County, Kentucky. A stable group of over 27 families in the Pure Church tradition continues at Cane Creek under the leadership of Bishop Louis Beachy. The group makes partial use of automobiles, with some members designated to drive when needed. Additional communities were founded in Danville, OH (1992), and Pearisburg, VA (mid-2000s), consisting mostly of former Amish. This set of churches uses the name "Believers in Christ."

\section{The Christ's Assemblies Movement [1960s-1990s]}

The Christ's Assemblies movement formed during the 1960s and 70s when a number of Anabaptist background families and single individuals of North America met Johannes Talitzer from Denmark, the leader and chief inspiration of a small pietistic group with spiritual connections back to The Brethren of Early Christianity (a communal group established near Kitchener, Ontario, by Julius Kubassek); to the Kornthal community in Württemberg, Germany; to the Zoar community in Ohio; to the Harmonists in western Pennsylvania (the Rappists); and the Ephrata community of Lancaster County, Pennsylvania, during the $18^{\text {th }}$ and $19^{\text {th }}$ centuries. Drawing members of Old Order Mennonite, Brethren, and Amish background, the Christ's Assemblies movement began to form in Eaton, Ohio (the Brubaker, Keck, and Clapper families); in Adams County, Indiana (the Sprunger and Wanner families); and in the Waterloo Region of Ontario (Elvern and Clarence Bauman, and others). Two families from Mammoth Springs, Arkansas, joined the movement.

The focus of these assemblies, in true Pure Church form, revolved around the prompt returning of the Lord. Baptisms, communions, and regular services, including zealous music with instruments, were conducted by appointed brothers. One meetinghouse was erected in Ohio. 
Otherwise, these members met in homes. Marriage and even procreation was discouraged in light of the Lord's prompt return. During its first 20 years, the Christ's Assemblies movement, both in the United States and Canada, attracted a good amount of interest from other Pure Church groups and seekers of many kinds. But by the mid-1990s, the movement was declining. Regular meetings ended in both Canada and Indiana. Today, the remnant in Ohio no longer holds to the practices or beliefs of the movement as it was established.

\section{The Anson Hoover Group (Ontario) [1974-1987]}

The Anson Hoover group separated from the Canadian Orthodox Mennonites in 1974 after the difficult merger of the Orthodox Mennonites and Noah Brubacher group seven years earlier. Several currents quickly became apparent, however, within the new fellowship. By 1976, Minister Anson Hoover (1920-2008), with a small circle of members, including ministers Amos Sherk and Menno Brubacher, held meetings independently. Others - those least inclined to adjust to the influence of the merged Amish Christian and Titus Hoover groups-went their own way with no other leadership than Deacon Tilman Hoover. When it became apparent that Anson Hoover had no desire to establish or lead a new congregation, and that he might be willing to extend the borders of his fellowship much further than before, Ministers Sherk and Brubacher temporarily rejoined the group with Tilman Hoover (Sherk taking on the office of voller Diener). Their union lasted until 1986, when Tilman Hoover with around 70 baptized members opted for a merger with the David Martin group. A number of families that declined the merger united under the leadership of Elam M. Martin (see below). But the ministers Amos Sherk, Menno Brubacher, and Jesse Bauman, with a small number of supporting members, moved to Huron County, Ontario. There, they became reunited with the Orthodox Mennonite Communities in 1987, Menno Brubacher (Anson Hoover's son-in-law) serving as bishop since 2001. The David Hoover family (Anson Hoover's son) and others that had established a small communal fellowship in the Waterloo Region also chose to reunite with the Orthodox Mennonites in 1987. Peter Hoover, another son, was ordained to the ministry in Mexico in 1981 (with the Nationwide Fellowship) but joined the Schmiedeleut Hutterites. The rest of those that constituted the Anson Hoover Group after 1976 have found their place among the Conservative Mennonite Church of Ontario, the Eastern Pennsylvania Mennonite Church, and the Washington-Franklin Mennonite Conference of Pennsylvania and Maryland. Anson Hoover served as a minister among the conservative Mennonites (Fellowship Churches) until shortly before his death in 2008.

\section{The Christian Pilgrims [1970s-1990s]}

Following the thoroughgoing repentance and renewal among the settlers at Muddy Pond Tennessee in the 1960s and its after-effects among those who had stayed with Noah Hoover in Pennsylvania, a number of members set out to establish a much more radical fellowship. Leading out among them were Daniel Bauman (brother to Lizzie Bauman of the Kitchener House Churches, brother-in-law to Anson Hoover of the Orthodox Mennonites); Eli Miller, who had come to Snyder County from the Amish through association with John W. Martin; and Leonard 
Kropf from the "sleeping preacher” Amish-Mennonites, who had married a daughter of Jerry Troyer from Hohenwald, Tennessee. During the 1970s and 1980s, the Christian Pilgrim movement incorporated people from the Amish settlement at Salem, Indiana; from the Old Colony Mennonites in Manitoba; from the Cane Creek Community at Lobelville, Tennessee; and form a number of ex-members of a Church of God in Christ, Mennonite (Holdeman) congregation in Ohio. In the periphery of this group were French-speaking seekers from Montreal, Quebec; various individuals from the Kitchener House Churches; and members from the Pilgrimage Valley and Barton Creek communities in Belize. A number of Christian Pilgrims with Leonard Kropf and James Overman began a new settlement near Punta Gorda, Belize, in the mid-1970s.

The Christian Pilgrims aimed to detach themselves as nearly as possible from this world's goods, to dedicate themselves totally to Christ in a loving (often itinerant) community. Even though they were itinerant and had no organized leadership, they made an impact on established churches, showing up anywhere and preaching whenever they caught an audience, from Manitoba to Ontario and south to Bolivia. Their dress was truly distinctive; they travelled on buses, flew as needed, and walked along the roads a lot, singing as they went, taking food and lodging "as the Lord provided." Their meetings, held at unfixed locations wherever they went, included spontaneous singing from the Scriptures and extemporaneous preaching. By the mid1990s, however, the movement had largely dissipated. Some joined the community at Cane Creek. Daniel Bauman and others found their way into the Remnant (Charity) Movement. In the mid-1990s, the Leonard Kropf family began a new settlement at Ixiamas in north-central Bolivia.

\section{The Reinland / Campo Alto Community (Paraguay) [1980-c.1995]}

The Reinland community in the district of Caaguazú, Paraguay, was established in 1980 by a group of 13 families under the leadership of ministers Johann Wall and Johann Dyck of the Lower Barton Creek Community in Belize. The group had earlier established contact with the ultra-conservative Sommerfelder community at San Ignacio, Misiones, Paraguay, and Jakob Funk from there assumed the responsibility of Aeltester (bishop) at Reinland until Bernhard Wall moved in from Barton Creek. For a number of years, the people at Reinland-including numerous couples of the extended Penner family of Barton Creek-made considerable progress, clearing virgin rainforest and making roads entirely with hand tools and horse-drawn implements. The original 600 hectare tract of land was divided into 40 hectare plots for each family to use. But by the early 1990s, most plots had been abandoned and the buildings either stood empty or were occupied by Paraguayans. A number of families from Reinland moved back to Barton Creek in Belize. Others moved to Canada, joining the Orthodox Mennonites in Ontario, or the Kleine Gemeinde in Nova Scotia. Some families, having united with the Rio Corriente Community (Fellowship Churches) in Paraguay, eventually moved to Canada as well, and nothing remained of the Reinland settlement by c.1995. 


\section{The Elam M. Martin Group (Ontario)* [1986-present]}

After the Anson Hoover Group disbanded, many having scattered, returned to the Orthodox Mennonites, or joined the David Martin Group by 1986-87, those who declined to make any move regrouped under Elam M. Martin, whom they elected to the ministry c.1989. For a number of years, this group continued to worship in what had been the first Orthodox Mennonite Meetinghouse east of Linwood, Ontario. But after Elam M. Martin died c.2002, the membership declined rapidly. Minister Alvin Martin led a small group to Durham, in Grey County, Ontario. Most of the remaining members sought unity with the Orthodox Mennonites who once again began to hold meetings in the Waterloo Region to accommodate them, after a lapse of more than thirty years. A small remnant of the Elam M. Martin Group continues to meet in homes in Wellesley and Peel Townships.

\section{The Christian Communities (Tennessee) [1990-2001]}

During the mid-1950s, numerous Amish families from Indiana, Ohio, and Michigan settled around Aylmer in Elgin County, Ontario, Canada. Peter Stoll (1912-1971), brother to Albert Stoll of St. Joe, Arkansas, later Pilgrimage Valley, Belize, soon established contact with the Orthodox Mennonites in Ontario, Anson Hoover, in particular. After Peter Stoll with a group of families moved to Guaimaca, Honduras, in 1969, his son Elmo (1944-1998) was ordained to the ministry at Aylmer in 1971. Very active as an editor for the Pathway Publishing Company he helped to establish, Elmo Stoll became widely known among conservative Anabaptists and was ordained bishop at Aylmer in 1984. Remaining in contact with the Orthodox Mennonites-Anson Hoover's sons David and Peter Hoover in particular, both of whom had strong communitarian leanings-Stoll also met Reinhold Konrath of the Kitchener House Churches and came under the influence of the Bruderhof Communities in New York and Pennsylvania. By September 1990, he and another Amish family from Aylmer, bought a tract of land and established the Cookeville Christian Community in Overton County, Tennessee. After a significant number of Old Order Mennonites from Pennsylvania and Kentucky joined the movement, another community took shape at Decatur, in Meigs County, Tennessee, in 1993. During the mid-1990s, Deacon Levi Shirk and Russell Shirk established a third Christian Community at Holland, Kentucky from members of the Scottsville Mennonite community. In response to requests from Amish families and Orthodox Mennonites, they established a community at Woodstock, New Brunswick, Canada, in 1994. A companion Christian Community took shape across the United States border near Smyrna, in Aroostook County, Maine, in 1995. During the mid-1990s, a number of families from German Baptist backgrounds joined the Christian Communities, including Bryce Geiser, ordained as a minister at Cookeville c.1994. To this number were added seekers from an unusually wide range of backgrounds, all willing to live without electricity, using only horse-drawn farm equipment and transportation. The communities prospered and were very active in publishing and outreach work until Elmo Stoll suddenly died in 1998. After that, the Woodstock, New Brunswick, community disbanded-some scattering, some returning to the Orthodox Mennonites, others becoming part of the Remnant (Charity) 
Churches. The Smyrna community (along with the Stoll family and others) joined the Amish. The Decatur and Holland communities merged with the one at Scottsville Mennonites. The community at Cookeville, Tennessee, also disbanded, some of its members still living on what had been the communal property and associating with the Remnant Churches. In 2005, a number of former members of the communities, under the leadership of Bryce Geiser, regrouped to establish a new community at Caneyville in Grayson County, Kentucky. From that time, the work has grown steadily and appeared to be in a stable prosperous condition by 2010 .

\section{The Jacob Oberholtzer Group (Kentucky / Tennessee)* [c.2000-present]}

Ordained in Lancaster County in 1949, Minister Jacob Oberholtzer moved with a group of members to Union County, Pennsylvania, in 1960, hoping to establish a more orderly church fellowship within the Groffdale Old Order Mennonite Conference. Living in Union County, he began a long-lasting and far-reaching relationship with the Orthodox Mennonites from Canada. (Jacob Oberholtzer's brother, John Oberholtzer, moved to Muddy Pond, Tennessee, where he became involved in the Joshua Bauman group, but later established a small movement of his own, moving to Pilgrimage Valley, Belize, in 1975.) In 1967, Jacob Oberholtzer, with a group of supporting members, founded a new settlement in Franklin County, Pennsylvania. When he left to establish yet another settlement in Casey County, Kentucky, Jacob’s co-worker, Deacon Adam Reiff, sought fellowship with the Orthodox Mennonites. (Reiff was still holding meetings in Rockingham County, Virginia, at the time.) Reiff later joined the Scottsville Mennonite Community. In Kentucky, Jacob Oberholtzer continued to work for greater church purity within the Groffdale Conference. In 1994, his son David Oberholtzer became active as a minister at the Decatur (later Delano) Christian Community in Tennessee, where he now serves as a bishop in fellowship with the Scottsville Mennonite Communities. Levi Newswanger, another minister with Jacob Oberholtzer, joined the Holland community (associated with Scottsville) in 1998. Numerous other members left Casey County, KY, to form new Orthodox Mennonite Communities in Trigg and Christian Counties, Kentucky, during the 1990s. After his ordination as a bishop in 2000, Jacob Oberholtzer and a sizeable group of members in his district had their connection to the Groffdale Old Order Mennonites come under question. Groffdale Conference decided that if the group would migrate, they could remain in fellowship with Groffdale. Jacob's group of 30-40 families moved to Spencer, TN, in 2013 and established the Spencer Mennonite Conference yet remaining in fellowship with Groffdale. Unlike Groffdale Conference, the group has no grid electric, relies on hydraulics for power, has no tractors, and has a community phone.

\section{The Gladstone Group (Manitoba) [2007-present]*}

In 2007 a group of ten families with a number of single members separated from the North Kinloss Orthodox Mennonite community in Huron County, Ontario, to move to Gladstone, Manitoba, Canada, under the leadership of Minister Alvin Weber and Deacon Amsey Bauman. The group has drawn considerable media attention for being the first settlement of 
horse and buggy driving plain people in Western Canada and also because of a government raid and subsequent prosecution of church members and leaders for alleged child abuse.

\section{Conclusion}

Over 100 years after the beginning of the Pure Church Movement and 50 years after its most turbulent decades (from the 1950s through the 1970s), the picture of what brought it into being, and of what remains, has emerged. Two distinct currents are evident. The first consists of the groups within it that adopted Pure Church principles but remain basically Old Order in lifestyle and outlook. This includes the David Martin Group in Canada, the Reidenbach Groups in Pennsylvania, and the John Dan Wenger Group in the Shenandoah Valley of Virginia.

The second, much more radical stream, includes what is left of most of the remaining, drawn by now into three basic spheres of influence: the Orthodox Mennonite Communities in Canada; the Hoover Mennonites of Scottsville, KY, Upper Barton Creek, Belize, and elsewhere; and the Believers in Christ communities, including the original Cane Creek Mennonite Community in Lobelville, TN.

For its intensity, its resilience, its perennial optimism in the face of what it sees as the apocalyptic apostasy and ruin of modern times, the Pure Church Movement stands alone. Of all revivals among post-Reformation Anabaptists, the revival of the Pure Churches is arguably the only one to have survived its first 100 years, standing in closer unity with, and more solidly grounded upon Anabaptist teachings than when it began. Judging by its performance during the first century of its existence, it may well be one of the most likely Anabaptist movements to survive the postmodern age.

\section{Endnote}

${ }^{1}$ The term group as used in this article corresponds to the German Leut as used within the Pure Church Movement (i.e. David Martileut for David Martin Group). The term community corresponds to the Movement's use of the German word Gmeh or Jemeent (dialectic for Gemeinde).

${ }^{2}$ Without a doubt, the most influential person to have come into contact with the Pure Church Movement through the Kitchener House Churches was Reinhold Konrath, a Nazarene (i.e. Apostolic Christian) immigrant from Serbia. Committed to life in Christian community, with strong connections to Julius Kubassek’s Brethren of Early Christianity, the Hutterites, and the Bruderhof Movement, Konrath attended meetings among the Orthodox Mennonites for years. He became a major influence in moving them, particularly the Anson Hoover family (see Anson Hoover Group) and the Christian Communities (led by Elmo Stoll) toward total Gelassenheit (detachment) in community of goods. 


\section{References}

Albertsen, Karsten-Gerhard 1996. The History \& Life of the Reidenbach Mennonites (Thirty Fivers). Schobüllhuus, Schleswig-Holstein, Germany: Karsten-Gerhard Albertsen.

Anson Hoover Papers and Letter Collection. Unpublished. Stored at the Rocky Cape Christian Community library, Tasmania, Australia.

Diaries of Anson Hoover 1944-1995. Unpublished. Stored at the Rocky Cape Christian Community library, Tasmania, Australia.

Luthy, David. 1975. “Martin Printers.” Family Life 8(12):15-18.

Martin, Donald. 2003. Old Order Mennonites of Ontario: Gelassenheit, Discipleship, Brotherhood. Kitchener, ON, Pandora Press.

Schrock, Frederick. 2002. The Amish Christian Church. Altamont, TN.

Scott, Stephen 1996. An Introduction to Old Order and Conservative Mennonite Groups. Intercourse, PA, Good Books.

Sherk, Amos M. General Records of the Orthodox Mennonite Church 1917-2007. Wroxeter, Ontario. Unpublished.

Uncle Aaron Stauffer’s Diary 1947-1956. 1995. Port Treverton, PA. 